\title{
PENGEMBANGAN MEDIA INTERNET UNTUK \\ MENINGKATKAN MOTIVASI DAN HASIL \\ BELAJAR MAHASISWA SYA'RIAH \\ STAIN MANADO
}

\author{
Munir Tubagus \\ STAIN Manado \\ tubagus@yahoo.co.id
}

\begin{abstract}
Abstrak
Penelitian ini bertujuan untuk: 1) Mengetahui apakah mahasiswa Jurusan Syari'ah telah memanfaatkan internet sebagai sumber belajar. 2) Mengetahui alasan apa yang memotivasi mahasiswa Jurusan Syari'ah telah memanfaatkan internet sebagai sumber belajar. Subyek penelitian adalah mahasiswa Jurusan Syari'ah STAIN Manado angkatan 2011, 2012. Jumlah subyek dalam penelitian ini 90 orang dengan perincian 45 mahasiswa angkatan 2011 dan 45 mahasiswa angkatan 2012 yang tersebar di Jurusan Syari'ah, terdiri dari 20 pertanyaan kuesioner. Adapun teknik yang digunakan dalam pengambilan subyek adalah dengan kriteria tertentu, yaitu teknil purposive sampling.

Berdasarkan hasil analisis regresi peranan internet dalam meningkatkan motivasi belajar mahasiswa dapat disimpulkan bahwasanya terdapat korelasi antara peranan internet dalam meningkatkan motivasi belajar mahasiswa yang dibuktikan dengan besaran nilai koefisien korelasi sebesar 0,726 dengan sig 0,000 $<0,05$ berarti berkorelasi secara signifikan. Hasil regresi diperoleh koefisien determinasi Adjusted $R 2$ sebesar 0,726 angka tersebut memberikan petunjuk bahwa peranan internet berpengaruh terhadap motivasi belajar mahasiswa sebesar $72,60 \%$. Sisanya sebesar $27,40 \%$ merupakan variasi atau pengaruh variable lain yang tidak diteliti dalam kajian ini. Misalnya, latar belakang orang tua, prasarana belajar kampus, dan buku paket belajar dan lain-lain. Hasil regresi antara peranan internet terhadap motivasi belajar mahasiswa diperoleh persamaan sebagai berikut: Besarnya koefisien konstanta (bo) = 5,933 dengan nilai t hitung sebesar
\end{abstract}


2,889 pada nilai Sig $0,000<0,05$ yang berrati bahwa koefisien signifikan berpengaruh. Nilai bo sebesar 5,933 dapat diartikan bahwa nilai motivasi sebesar 5,933 satuan apabila peranan internet sama dengan Nol. Besar koefisien regresi variabel peranan internet $(b x)=0,105$ dengan nilai t hitung sebesar 6,927 pada nilai Sig 0,000 < 0,05 yang berarti koefisien regresi untuk peranan internet adalah signifikan berpengaruh, Nilai koefisien bx sebesar 0,105 memberikan arti setiap peningkatan peranan internet dapat meningkatkan motivasi belajar sebesar 0,105 satuan.

\section{Kata Kunci: Teknologi, Internet, Motivasi Belajar Mahasiswa}

\section{A. Pendahuluan}

Seiring dengan perkembangan ilmu pengetahuan dan teknologi dewasa ini. Internet merupakan salah satu sarana pertukaran data/informasi yang paling cepat sampai dengan hari ini. Disamping itu, internet telah menjadi tempat dimana orang mencari informasi dari mulai informasi yang bersifat hiburan, olah raga, politik, bisnis, ekonomi, dunia pendidikan, serta teknologi informasi apa saja yang berkaitan dengan kehidupan manusia pada umumnya. Dalam hubungannya dengan dunia pendidikan, internet telah menjadi sarana untuk mendapatkan informasi atau data yang tersimpan di server-server yang tersebar di seluruh dunia yang dapat diakses dan dibaca secara cepat, mudah dan cuma-cuma oleh para pengunjung internet (netter). Dengan kata lain internet merupakan tempat yang penting bagi dunia pendidikan.

Dengan dikenalkannya teknologi World Wide Web (WWW) pada tahun 1990an, maka internet dapat menampilkan "halaman-halaman" yang tidak hanya berisi teks saja, tetapi juga gambar, grafik, animasi, dan suara yang menarik dan penuh dengan warna-warni, sehingga internet bagi sebagian orang telah digunakan sebagai pengganti televise karena internet telah mampu menampilkan layanan multimedia, yaitu data, citra dan suara. 
Semakin bertambah kemampuan internet dalam menampilkan tampilan yang menarik dan kecepatan yang semakin tinggi, maka semakin banyak orang menjadikan internet tidak hanya untuk mencari informasi tetapi juga hiburan. Berdasarkan penelitian, hampir 90\% mahasiswa di Amerika mencari informasi yang berkaitan dengan studi mereka melalui internet. Dalam setiap detik ada sekitar 7 orang yang mulai belajar dengan meng-klik mouse untuk memasuki dunia maya ini.

Dalam dunia pendidikan, perkembangan ilmu pengetahuan dan teknologi khususnya teknologi informasi sekarang ini telah memberikan dampak positif dalam semua aspek kehidupan manusia terutama aspek pendidikan. Terjadi perubahan dalam proses pembelajaran, yaitu pembelajaran yang biasanya dilakukan terbatas diruang kelas dengan jadwal yang telah ditentukan, sekarang dapat diakses dengan internet. Pembelajaran yang biasanya hanya memanfaatkan buku-buku teks bacaan sekarang berkembang dengan memanfaatkan computer dan internet. Perkembangan dan kemajuan teknologi internet yang sangat pesat dan merambah keseluruh penjuru dunia telah dimanfaatkan oleh berbagai negara untuk berbagai kepentingan termasuk didalamnya untuk pendidikan atau pembelajaran.

Penggunaaan internet untuk pendidikan yang semakin meluas terutama di negara-negara maju dan berkembang, merupakan fakta yang menunjukkan bahwa dengan media internet memang dimungkinkan diselenggarakannya kegiatan belajar yang lebih efektif. Hal tersebut terjadi karena sifat dan karakteristik internet yang cukup memadai, sehingga diharapkan dapat digunakan sebagai media pembelajaran. Oleh karena itu, internet diharapkan mampu memberikan informasi tentang materi pelajaran yang diperlukan sehingga dapat membantu mahasiswa dalam menyelesaikannya tugas-tugas pelajaran dari dosen sehingga dapat meningkatkan prestasi belajar mahasiswa.

Keberhasilan kegiatan belajar mengajar di perguruan tinggi tidak hanya ditentukan oleh faktor pengajar/dosen, melainkan sangat dipengaruhi oleh keaktifan mahasiswa. Kurikulum perguruan tinggi mempertegas bahwa proses pembelajaran harus berpusat pada peserta belajar, pengajar bukan sebagai satu- 
satunya sumber belajar atau sumber informasi, melainkan berperan sebagai fasilitator, dinamisator, dan motivator dalam pembelajaran.

Selain sumber belajar berupa perpustakaan yang tersedia di kampus, sekarang ini berkembang teknologi internet yang memberikan kemudahan dan keleluasaan dalam menggali ilmu pengetahuan. Melalui internet mahasiswa dapat mengakses berbagai literature dan refrensi ilmu pengetahuan yang dibutuhkan dengan cepat, sehingga dapat mempermudah proses studinya. Penelitian ini ingin mengetahui sejauh mana mahasiswa Jurusan Syari'ah STAIN Manado memanfaatkan teknologi internet sebagai sumber belajar untuk meningkatkan motivasi dan hasil belajar dalam mendukung proses belajar di bangku kuliah.

Berdasarkan permasalahan yang diangkat diatas, tujuan yang ingin dicapai dalam penelitian ini adalah untuk mengetahui apakah mahasiswa Jurusan Syari'ah telah memanfaatkan internet sebagai sumber belajar, dan mengetahui alasan apa yang memotivasi mahasiswa Jurusan Syari'ah telah memanfaatkan internet sebagai sumber belajar.

Apabila tujuan penelitian ini tercapai, manfaat yang diharapkan dari penelitian yang dilakukan adalah hasil penelitian akan menjadi informasi actual yang dapat memperkaya khasanah pengetahuan tentang media internet sebagai peningkatan hasil belajar mahasiswa, sehingga mempercepat masa studinya. Untuk jurusan Syari'ah, sebagai bahan pertimbangan dalam membuat kebijakan dan program kerja yang berkaitan dengan fasilitas sumber belajar. Bagi peneliti, sebagai dorongan untuk lebih meningkatkan penguasaan teknologi informasi sehingga dapat memperbaiki kemampuan dalam mengajar.

\section{Pengertian Internet}

Sistem internet adalah kependekan dari inter-network. Secara harfiah mengandung pengertian sebagai jaringan computer yang menghubungkan beberapa rangkaian. ${ }^{1}$ Jaringan internet juga didefinisikan sebagai jaringan computer yang mampu menghubungkan computer di seluruh dunia sehingga berbagai jenis dan bentuk informasi dapat dikomunikasikan antar belahan dunia

\footnotetext{
${ }^{1}$ Anonim, (2008). Wikipedia.com
} 
secara instan dan global (www.jurnal-kopertis4.org). ${ }^{2}$ Selain kedua pengertian di atas, internet juga disebut sebagai sekumpulan jaringan computer yang menghubungkan situs akademik, pemerintahan, komersial, organisasi, maupun perorangan. Internet menyediakan akses untuk layanan telekomunikasi dari sumber daya informasi untuk jutaan pemakainya yang tersebar di seluruh dunia. Layanan internet meliputi komunikasi langsung (e-mail, chat), diskusi (usenet news, milis, bulletin board), sumber daya informasi yang terdistribusi (World Wide Web, Ghoper), remote login dan lalu lintas file (Telnet, FTP), serta berbagai layanan lainnya (www.andhika.com) ${ }^{3}$

Sejalan dengan perkembangan internet, telah banyak aktivitas yang dilakukan dengan memanfaatkan jaringan internet, seperti e-Commerce, e-Banking, $e$ Government, e-Learning dan lainnya. Salah satu aktivitas yang berkaitan dengan proses pembelajaran adalah e-Learning. E-Learning adalah wujud penerapan teknologi informasi di bidang pendidikan dalam bentuk sekolah maya. E-Learning merupakan usaha untuk membuat sebuah transformasi proses belajar mengajar di sekolah dalam bentuk digital yang dijembatani oleh teknologi internet.

\section{Fungsi dalam Internet}

Menurut Hariningsih, ada 3 fasilitas/aplikasi utama dari TCP/IP (Transmission Control Protokol/Internet Protokol) adalah sebagai berikut:

1) Elektronik Mail/e-mail/Messaging

Elektronik mail atau surat elektronik adalah fasilitas yang paling sering digunakan di internet. Dengan fasilitas ini seseorang dapat membuat dan mengirimkan pesan tertulis kepada seseorang atau sekelompok orang lain yang juga terdaftar di internet.

2) Remote Login

Dengan fasilitas ini, seseorang dapat mengakses program/aplikasi di komputer lain. Misalnya seseorang peserta didik di sekolah A dapat menjalankan aplikasi komputer yang terdapat di sekolah B tanpa harus

${ }^{2}$ Anonim. (2008). Sekilas Perkembangan Internet di Indonesia. www.jurnalkopertis4.org. diambil 24 April 2012.

${ }^{3}$ Andhika. (2008). Apa Itu Internet? www.andhika.com diakses 25 April 2012. 
datang ke sekolah B apabila komputer di sekolah A dan B berhubungan menggunakan TCP/IP (Transmission Control Protokol/Internet Protokol).

3) File Transfer

Fasilitas ini memungkinkan terjadinya pengiriman file dari satu komputer ke komputer lain. Sebuah file dapat berisi dokumen, grafik, program computer, bahkan video maupun suara yang terekam secara digital. ${ }^{4}$

\section{Internet dalam Kegiatan Belajar}

Fred S Keller, teknologi pendidikan era tahun 1960-an mengkrtik penerapan metode-metode pembelajaran konvensional yang kurang menarik perhatian peserta didik. Menurut dia, peserta didik harus diberi akses yang lebih luas dalam menentukan apa yang ingin mereka pelajari sesuai minat, kebutuhan, dan kemampuannya. Dikatakannya pula bahwa guru bukanlah satu-satunya pemegang otoritas pengetahuan di kelas. Siswa harus diberi kemandirian untuk belajar dengan memanfaatkan berbagai sumber belajar. ${ }^{5}$

Para akademisi merupakan salah satu pihak yang paling diuntungkan dengan kemunculan internet. Berbagai referensi, jurnal, maupun hasil penelitian yang dipublikasikan melalui internet tersedia dalam jumlah yang berlimpah. Para mahasiswa tidak lagi harus mengaduk-aduk buku di perpustakaan sebagai bahan untuk mengerjakan tugas-tugas kuliahnya. Cukup memanfaatkan search engine, materi-materi yang dibutuhkan dapat diperoleh dengan cepat. Selain menghemat tenaga dan biaya dalam mencarinya, materi-materi yang dapat ditemui di internet cenderung lebih up to date.

Bagi para pengajar, internet bermanfaat dalam mengembangkan profesinya, karena dengan internet dapat: a) meningkatkan pengetahuan, b) berbagi sumber diantara rekan sejawat, c) bekerjasama dengan pengajar di luar negeri, d) kesempatan mempublikasikan informasi secara langsung, e) mengatur komunikasi secara teratur, dan f) berpartisipasi dalam forum-forum local maupun internasional. Di samping itu, para pengajar juga dapat memanfaatkan internet sebagai sumber bahan mengajar dengan mengakses rencana pembelajaran atau

\footnotetext{
${ }^{4}$ Hariningsih, “Teknologi Informasi”, Penerbit : Graha Ilmu, Yogyakarta: 2005, h. 138

${ }^{5}$ Marsell Ruben Payong. (2008). Good Bye Teacher. www.kompas.com. Diambil 24 Mei 2012.
} 
silabus online dengan metodologi baru, mengakses materi kuliah yang cocok untuk mahasiswanya, serta dapat menyampaikan ide-idenya.

Sementara itu mahasiswa juga dapat menggunakan internet untuk belajar sendiri secara cepat, sehingga akan meningkatkan dan memperluas pengetahuan, belajar berinteraksi, dan mengembangkan kemampuan dalam bidang penelitian (www.pendidikan.net). ${ }^{6}$

\section{Pengertian Sumber Belajar}

Menuut Association for Educational Communication and Technology sumber pembelajaran adalah segala sesuatu atau daya yang dapat dimanfaatkan oleh guru, baik secara terpisah maupun dalam bentuk gabungan, untuk kepentingan belajar mengajar dengan tujuan meningkatkan efektifitas dan efisiensi tujuan pembelajaran. Sumber pembelajaran dapat dikelompokkan menjadi dua bagian, yaitu:

1) Sumber pembelajaran yang sengaja direncanakan (Learning resources by design), yakni semua sumber yang secara khusus telah dikembangkan sebagai komponen sistem instruksional untuk memberikan fasilitas belajar yang terarah dan bersifat formal, dan

2) Sumber pembelajaran yang karena dimanfaatkan (Learning resources by utilization), yakni sumber belajar yang tidak secara khusus didesain untuk keperluan pembelajaran namun dapat ditemukan, diaplikasikan, dan dimanfaatkan untuk keperluan belajar salah satunya adalah media massa. Media massa adalah suatu jenis komunikasi yang ditujukan kepada sejumlah khalayak yang tersebar, heterogen, dan anonym melewati media cetak atau elektronik, sehingga pesan informasi yang sama dapat diterima secara serentak dan sesaat. Pengertian "dapat" disini menekankan pada pengertian, bahwa jumlah sebenarnya penerima pesan informasi melalui media massa pada saat tertentu tidaklah esensial. Yang penting ialah "The communicatior is a social organization capable or reproducing the message and sending it simultaneously to large number of people who are

\footnotetext{
2012.
}

${ }^{6}$ Philip rechdalle. (2008). Internet dan Pendidikan (www.pendidikan.net) diambil 24 Mei 
spartially separated”. Adapun bentuk media massa, secara garis besar, ada dua jenis, yaitu : media cetak (surat kabar dan majalah, termasuk bukubuku) dan media elektronik (televise dan radio, termasuk internet). ${ }^{7}$

Berdasarkan kajian pustaka di atas menunjukkan bahwa peningkatan kualitas pendidikan di perguruan tinggi dapat ditempuh melalui berbagai cara, antara lain: peningkatan kompetensi dosen, peningkatan muatan kurikulum, peningkatan kualitas pembelajaran dan penilaian hasil belajar, peningkatan kualitas pembelajaran dan penilaian hasil belajar, peningkatan bekal keterampilan mahasiswa, penyediaan bahan ajar yang memadai, dan penyediaan sarana belajar. Ketersediaan bahan ajar dan sarana belajar merupakan faktor penting dalam menunjang keberhasilan proses pembelajaran. Namun demikian sering kali bahan ajar yang ada di perpustakaan tidak mampu memenuhi kebutuhan belajar mahasiswa, sehingga perlu memanfaatkan sumber belajar yang lain. Salah satu sumber belajar yang dapat digunakan oleh mahasiswa secara mandiri adalah jaringan internet. Untuk itu, bekal keterampilan mahasiswa khususnya dalam memanfaatkan teknologi internet sangat diperlukan. Melalui internet, mahasiswa dapat mengakses berbagai informasi dan ilmu pengetahuan sesuai kebutuhan yang relevan dengan subjek mata kuliah. Sehingga pemanfaatan jaringan internet sebagai sumber belajar, akan membantu mempermudah dan mempercepat penyelesaian tugas-tugas perkuliahan, termasuk penyelesaian tugas akhir. Oleh karena itu, dosen sebagai motivator dan dinamisator dalam pembelajaran hendaknya memberi dorongan serta menciptakan kondisi agar mahasiswa dapat secara aktif menemukan ilmu pengetahuan baru melalui pemanfaatan teknologi internet.

\section{Motivasi Belajar}

Motif adalah kekuatan yang memobilisasi dan menyalurkan energi itu sendiri digerakkan oleh suatu keadaan tertentu yang mendorong suatu organisme ke arah keadaan tertentu. Dalam kegiatan proses belajar akan berhasil baik, kalau siswa tekun mengerjakan tugas, ulet dalam memecahkan berbagai masalah dan hambatan secara mandiri. Siswa yang belajar dengan baik tidak akan terjebak

\footnotetext{
${ }^{7}$ http://www.artikel.us/mangkoes6-04-2.html. Diambil 25 Juni 2012.
} 
pada sesuatu rutinitas dan mekanis, mampu mempertahankan pendapatnya kalau diyakini dan dipandangnya cukup rasional. Bahkan seorang siswa yang memiliki motivasi belajar yang kuat peka dan responsive terhadap berbagai masalah umum, dan memikirkan bagaimana pemecahannya. Diantara ciri orang yang termotivasi adalah cepat bosan dengan tugas-tugas rutin dan tidak cepat puas dengan hasil yang telah didapatkan. Sedangkan menurut Frandsen dan Sadirman (2000) disebutkan bahwa hal yang mendorong seseorang untuk belajar diantaranya adalah selalu ingin tahu dan adanya keinginan untuk memperbaiki kegagalan di masa lalu dengan usaha yang keras.

Dalam disiplin ilmu psikologi, motivasi mengacu pada konsep yang digunakan untuk menerangkan kekuatan-kekuatan yang ada dan bekerja pada diri organisme atau individu yang menjadi penggerak dan pengarah tingkah laku individu tersebut untuk mencapai suatu tujuan tertentu. Dengan motivasi, seseorang akan dapat melakukan suatu tindakan. Jika tidak ada motivasi, maka individu tidak akan dapat mencapai tujuannya. Berikut ini adalah beberapa definisi motivasi dari para ahli antara lain:

"A motive is an inner state that energizes activates, or moves (hence 'motivation'), and that directs or channels behavior toward goals" (Motif adalah keadaan dalam diri yang membangkitkan, mengatifkan, atau menggerakkan (selanjutnya disebut motivasi), dan mengarahkan atau menyalurkan tingkah laku pada tujuan (Luthan, F., 1981:150). "Motivation is usually defined as the process by which behavior is energized and directed". (Motivasi biasanya didefinisikan sebagai proses yang membangkitkan dan mengarahkan tindakan) (Wexley \& Yukl, 1977:75).

\section{Hipotesis Penelitian}

Wahidmumin mengemukakan bahwa "Hipotesis penelitian adalah rangkuman dari kesimpulan-kesimpulan teoritis yang diperoleh dari kajian pustaka. Hipotesis merupakan jawaban sementara terhadap masalah penelitian yang secara teoritis dianggap paling mungkin dan paling tinggi tingkat kebenarannya. ${ }^{8}$ Hipotesis

8 Wahidmumin, Cara Mudah Menulis Proposal dan Laporan Penelitian Lapangan (Malang: UM Press, 2008), hlm. 20 
terbagi atas dua jenis, yakni hipotesis nol (Ho) yang menyatakan tidak ada pengaruh atau tidak ada hubungan atau tidak ada perbedaan antara variabel $\mathrm{X}$ dan Variabel Y. hipotesis alternatif (H1) yang menunjukkan ada pengaruh atau ada hubungan atau ada perbedaan antara variabel $\mathrm{X}$ dan variabel $\mathrm{Y} .{ }^{9}$ Oleh karena itu, hipotesis nol dalam penelitian ini adalah sebagai berikut :

1. Tidak ada pengaruh positif signifikan dari media internet terhadap prestasi belajar mahasiswa jurusan Syari'ah STAIN Manado.

2. Tidak ada pengaruh positif signifikasi dari media internet terhadap motivasi belajar mahasiswa jurusan syari'ah STAIN Manado.

Adapun hipotesis alternative (H1) dari penelitian ini adalah sebagai berikut:

1. Ada pengaruh positif signifikasi dari media internet terhadap prestasi belajar mahasiswa jurusan syari'ah STAIN Manado.

2. Ada pengaruh positif signifikan dari media internet terhadap motivasi belajar mahasiswa jurusan syari'ah STAIN Manado.

\section{Metodologi Penelitian}

\section{a) Pendekatan dan Jenis Penelitian}

Dalam penelitian ini, menggunakan pendekatan kuantitatif deskriptif dengan metode statistik. ${ }^{10}$ Pendekatan ini digunakan oleh peneliti dalam rangka memperoleh hubungan antar variabel yang diteliti. Sedangkan jenis penelitian yang digunakan dalam penelitian ini adalah kausalitas korelasi dan regresi. Variabel bebas yang digunakan adalah pemanfaatan internet dan variabel terikat adalah motivasi belajar mahasiswa yang dinyatakan dalam hasil belajar atau prestasi belajar mahasiswa. Untuk membuktikan hipotesis digunakan model persamaan regresi sederhana $\mathrm{Y}=\mathrm{a}+\mathrm{bX}$, uji signifikasi dengan uji $\mathrm{t}$.

\section{b) Rancangan Penelitian}

Rancangan penelitian berfungsi untuk memperoleh data sesuai dengan karakteristik variabel dan tujuan penelitian. Penelitian ini hendak mengetahui

\footnotetext{
${ }^{9}$ Ibid, hlm. 21

${ }^{10}$ Azwar, metode Penelitian, (Yogyakarta: Pusat Belajar, 2005), h. 5
} 
hubungan variabel X1 variabel bebas (pemanfaatan internet) dan X2 variabel terikat (motivasi belajar) terhadap Y hasil belajar (prestasi belajar mahasiswa).

\section{Data dan Sumber Data}

Data adalah keterangan atau bahan nyata yang dapat digunakan dasar kajian baik sebagai analisis atau kesimpulan. ${ }^{11}$ Dengan demikian yang dimaksud data dalam

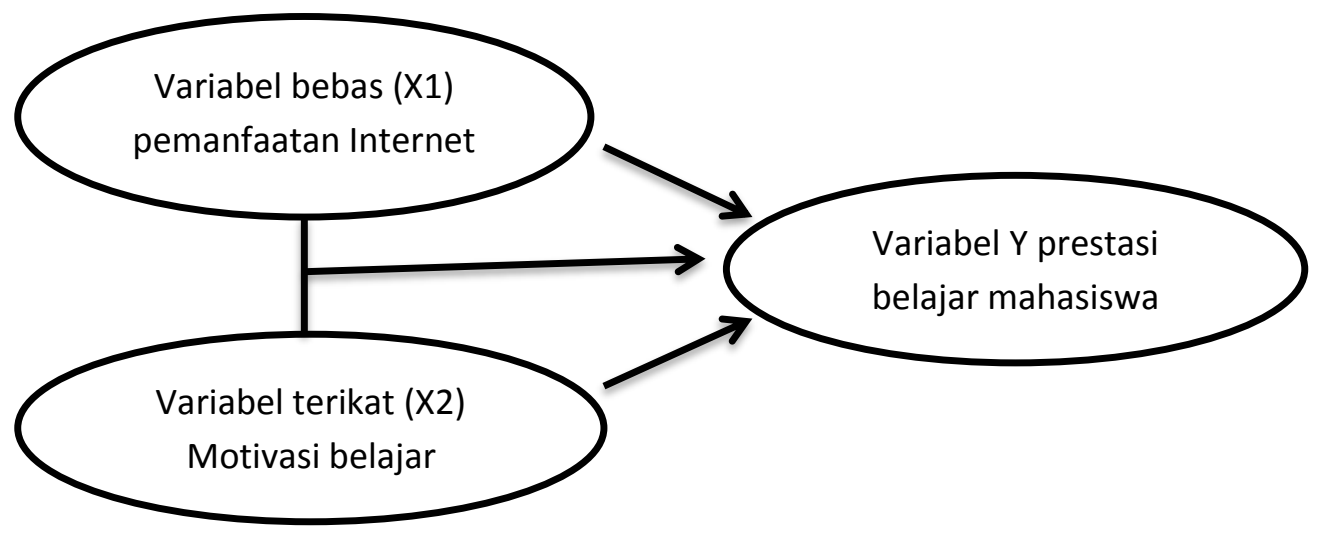

\section{Gambar 1.1}

\section{Kerangka Konseptual}

penelitian ini adalah berbagai keterangan atau informasi yang berkaitan dengan penelitian yang dilakukan. Sumber data merujuk pada diri mana data penelitian itu diperoleh, data dapat dari orang dan bukan orang. ${ }^{12}$

1. Data Primer

Data primer adalah data yang diperoleh atau dikumpulkan langsung di lapangan oleh orang yang dilakukan penelitian atau yang bersangkutan yang memerlukannya. Data primer ini disebut juga data asli atau data baru. ${ }^{13}$ Dan primer dalam penelitian ini diperoleh secara langsung dengan menggunakan angket yang disebarkan kepada mahasiswa selaku responden. Kemudian dikumpulkan, diolah dan disajikan oleh peneliti. Dalam penelitian ini data primernya melalui angket yang disebarkan kepada mahasiswa, angket manfaat

\footnotetext{
${ }^{11}$ Wahidmurni, Op.Cit, hlm. 41

12 Ibid, hlm. 41

${ }^{13}$ Iqbal Analisis Data Penelitian dengan Statistik: PT. Bumi Aksara, 2008), hlm. 19
} 
internet terhadap proses belajar mahasiswa dan motivasi belajar mahasiswa ini mencakup 4 indikator dan kembangkan dalam 20 pertanyaan.

2. Data Sekunder

Data sekunder adalah data yang diperoleh dari informasi yang telah diolah oleh pihak lain, segala macam bentuk dokumen. ${ }^{14}$ Data sekunder ini digunakan oleh peneliti untuk melengkapi data primer. Data sekunder dalam penelitian ini meliputi dokumen nilai ujian akhir semester mata pelajaran ilmu komputer.

\section{Desain Penelitian}

Penelitian ini menggunakan desain penelitian survey, yang dipakai untuk tujuan eksplorasi. Penelitian ini bertujuan untuk menggali informasi tentang pemanfaatan internet sebagai sumber belajar oleh mahasiswa Jurusan Syari'ah Sekolah Tinggi Agama Islam (STAIN) Manado.

\section{Populasi dan Sampel Penelitian}

\section{Populasi}

Populasi menurut Hadari Nawawi dalam metodologi penelitian pendidikan yang dikutip oleh S. Margono:

"Populasi adalah keseluruhan objek penelitian, yang terdiri dari manusia, benda-benda, hewan, tumbuh-tumbuhan, gejala-gejala nilai tes atau peristiwaperistiwa sebagai sumber data yang memiliki karakteristik tertentu dalam suatu penelitian". 15

Berdasarkan pendapat di atas maka yang dimaksud dengan populasi adalah sejumlah individu yang diteliti dalam suatu penelitian, sehingga penulis menentukan populasi penelitian ini adalah mahasiswa Jurusan Syari'ah Sekolah Tinggi Agama ISLAM (STAIN) Manado yang meliputi mahasiswa angkatan 2011 dan 2012.

\section{Sampling}

Dalam suatu penelitian, sering berhadapan dengan populasi yang banyak. Adapun pengertian dari metode sampling adalah "Memiliki sejumlah tertentu dari

${ }^{14}$ Wahidmurni, Op.Cit, hlm. 41

${ }^{15}$ Margono. S. Metodologi Penelitian Pendidikan, (Jakarta: Rineka Cipta, 2007), hlm. 
keseluruan populasi."16 Dalam pengertian yang lain metode sampling adalah teknik pengambilan sampel. ${ }^{17}$ Dari kedua definisi tersebut, dapat disimpulkan bahwa metode sampling adalah suatu cara dalam mengambil sampel dari suatu populasi sehingga contoh tersebut mewakili seluruh populasi.

\section{Teknik Pengumpulan Data}

Teknik pengumpulan data yang digunakan dalam penelitian ini adalah kuesioner (angket). Angket merupakan teknik pengumpulan data yang dilakukan dengan cara memberi seperangkat pertanyaan atau pernyataan tertulis kepada responden untuk dijawabnya. Angket merupakan teknik pengumpulan data yang efisien bila peneliti tahu dengan pasti variabel yang akan diukur dan tahu apa yang bisa diharapkan dari responden. Angket dapat berupa pertanyaan atau pernyataan tertutup/terbuka, dapat diberikan kepada responden secraa langsung atau dikirim melalui pos, atau internet. ${ }^{18}$

Metode yang digunakan peneliti dalam pengumpulan data yang diperlukan adalah dengan menggunakan angket dengan pernyataan tertutup. Pengumpulan data dengan menggunakan angket pada responden untuk mengisi daftar pertanyaan tentang pengaruh internet terhadap motivasi belajar mahasiswa. Penulis menggunakan skala likert yaitu: "metode yang mengukur sikap, pendapat dan persepsi seseorang dan sekelompok orang tentang fenomena sosial dengan menyatakan setuju atau tidak setuju terhadap subyek, obyek atau kejadian tertentu".

Teknik pengumpulan data berupa kuesioner tertutup dengan menggunakan skala likert pada 5 skala sbb:

1) Sangat Tidak Setuju (STS)

2) Tidak Setuju (TS)

3) Ragu-Ragu (RR)

4) Setuju (S)

5) Sangat Setuju (SS)

\footnotetext{
${ }^{16}$ Ibid, hlm. 86

${ }^{17}$ Sugiyono, Metode Penelitian Administrasi. (Bandung: Penerbit Alfabeta. 1999). Hlm.

${ }^{18}$ Sugiyono, Op.Cit, hlm. 199
} 
Instrument yang digunakan berdasarkan variabel yang diteliti dioprasionalkan pada Tabel 1.1.

\section{Teknik Analisis Data}

Data yang terkumpul akan dianalisis secara deskriptis dengan tabulasi dan persentase. Dengan demikian yang dimaksud data dalam penelitian ini adalah sebagai keterangan atau informasi yang berkaitan dengan penelitian yang dilakukan. Berdasarkan model statistika korelasi dan regresi yang digambarkan tersebut di atas, maka hipotesis dalam kajian ini dapat dilihat pada hasil penelitian dibawah ini.

\section{Tabel 1.1}

Operasionalisasi Variabel Penelitian

\begin{tabular}{|c|l|c|c|l|c|}
\hline \multicolumn{2}{|l|}{ Variabel Peranan Internet } & \multicolumn{3}{c|}{ Variabel Motivasi Belajar Mahasiswa } \\
\hline No & Dimensi & Butir & No & Dimensi & Butir \\
\hline 1 & $\begin{array}{l}\text { Kemudahan teknis } \\
\text { menggunakan }\end{array}$ & 1,2 & 1 & $\begin{array}{l}\text { Memberi Kemudahan } \\
\text { Belajar }\end{array}$ & 11,12 \\
\hline 2 & $\begin{array}{l}\text { Kemudahan mencari } \\
\text { informasi }\end{array}$ & 3,4 & 2 & $\begin{array}{l}\text { Memberi Inspirasi } \\
\text { Belajar }\end{array}$ & 13,14 \\
\hline 3 & $\begin{array}{l}\text { Pemanfaatan internet } \\
\text { (waktu \& biaya) }\end{array}$ & 5,6 & 3 & $\begin{array}{l}\text { Memberi wawasan dan } \\
\text { ilmu pengetahuan }\end{array}$ & 15,16 \\
\hline 4 & $\begin{array}{l}\text { Dukungan dan } \\
\text { bimbingan Dosen }\end{array}$ & 7,8 & 4 & $\begin{array}{l}\text { Dukungan dan } \\
\text { Bimbingan Dosen }\end{array}$ & 17,18 \\
\hline 5 & $\begin{array}{l}\text { Dampak negative dan } \\
\text { positif }\end{array}$ & 1,10 & 5 & $\begin{array}{l}\text { Tuntutan tugas dari } \\
\text { dosen }\end{array}$ & 19,20 \\
\hline
\end{tabular}

\section{Hasil dan Pembahasan}

Hasil penelitian kajian pengaruh peranan internet dalam motivasi belajar mahasiswa, berdasarkan hasil analisis dengan menggunakan SPSS dijelaskan sebagai berikut:

\section{a) Pengujian Instrumen Penelitian}

Instrumen penelitian yang digunakan diharuskan memiliki validitas dan reliabilitas agar diperoleh hasil analisis yang akurat, valid dan reliable. Hasil 
analisis instrument pengujian validitas dan reliabilitas diperoleh nilai untuk masing-masing butir instrument dilihat dari nilai sebagai berikut:

\section{Korelasi Peranan Internet dan Motivasi Belajar Mahasiswa}

Pengujian korelasi menyatakan kadar hubungan peranan internet terhadap motivasi belajar mahasiswa, diperoleh hasil sebagai berikut :

Tabel 1.2

\section{Hasil Pengolahan SPSS (correlations)}

\section{Correlations}

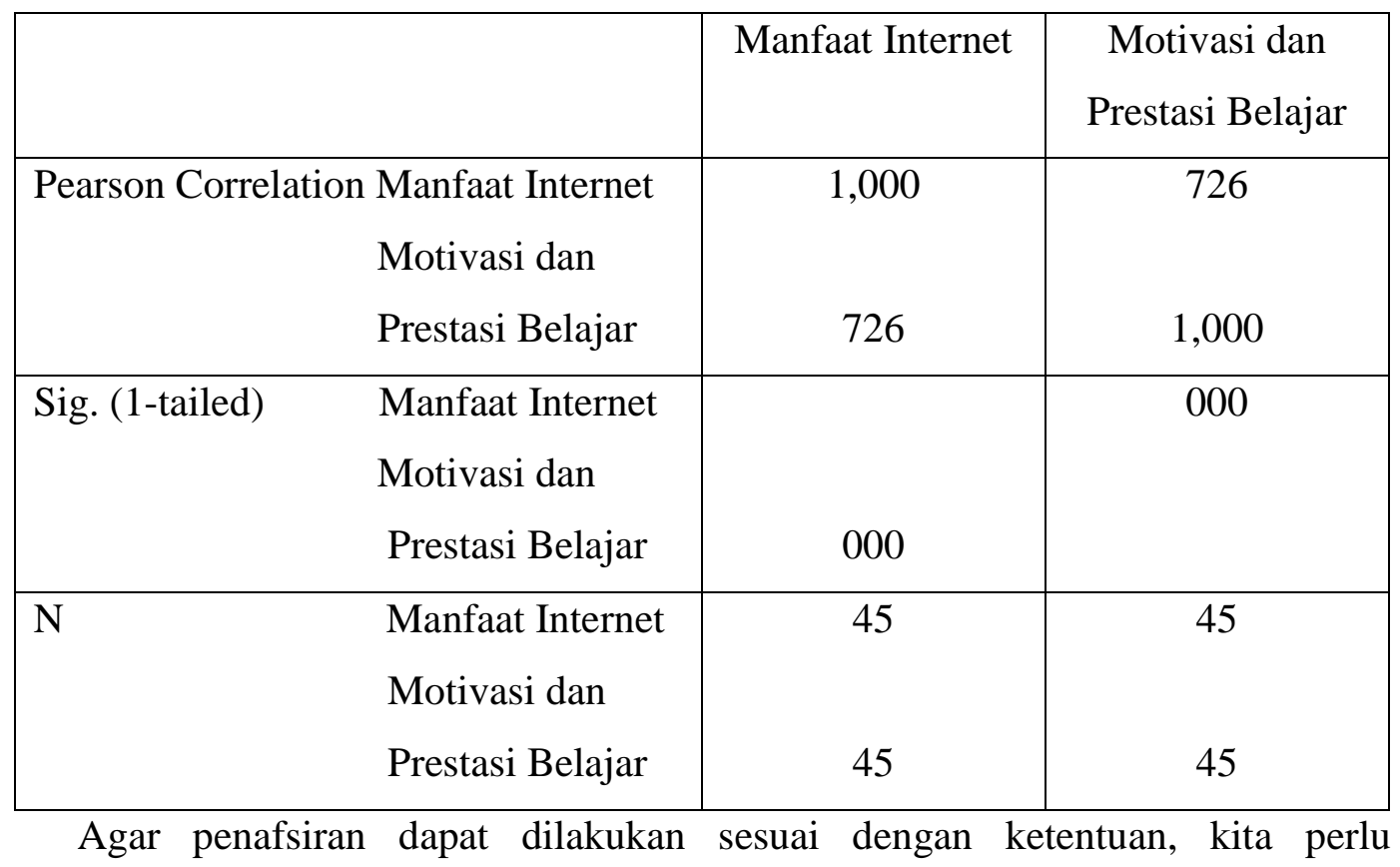

mempunyai kriteria yang menunjukkan kuat atau lemahnya korelasi. Kriterianya sebagai berikut :

1) Angka korelasi berkisar antara $0 \mathrm{~s} / \mathrm{d} 1$

2) Besar kecil angka korelasi menentukan kuat atau lemahnya hubungan kedua variabel. Patokan angkanya adalah sebagai berikut:
a) $0-0,25$
: Korelasi sangat lemah (dianggap tidak ada)
b) $>0,25-0,5 \quad$ : Korelasi cukup
c) $>0,5-0,75 \quad$ : Korelasi kuat
d) $>0,75-1 \quad$ : Korelasi sangat kuat

3) Korelasi dapat positif dan negative. Korelasi positif menunjukkan arah yang sama hubungan antar variabel, artinya jika variabel 1 besar, maka 
variabel 2 semakin besar pula. Sebaliknya korelasi negative menunjukkan arah yang berlawanan artinya jika variabel 1 besar maka variabel 2 menjadi kecil.

4) Sifnikasi hubungan dua variabel dapat dianalisis dengan ketentuan pengujian hipotesis dilakukan pada level $=0,05$ dengan kriteria pengujian yaitu :

a. Jika Probabilitas atau Signifikasi > 0,05 maka terima H0 : artinya tidak ada pengaruh peranan internet terhadap motivasi belajar mahasiswa.

b. Jika Probabilitas atau Signifikasi < 0,05 maka tolak H0 : artinya terdapat pengaruh dari peranan internet terhadap motivasi belajar mahasiswa.

5) Menafsir Angka Korelasi Perhitungan

Jika dilihat dari hasil perhitungan, maka korelasi antara variabel "peranan internet" dan "motivasi belajar" menunjukkan angka sebesar 0,726. Angka ini menunjukkan adanya korelasi yang kuat dan searah. Ini berarti, jika variabel peranan internet besar, maka variabel motivasi belajar akan semakin besar pula.

6) Menentukan Signifikasi Hasil Korelasi

Untuk mengetahui apakah angka korelasi tersebut signifikan atau tidak, lakukan langkah-langkah sebagai berikut :

Tentukan Hipotesis :

a. H0 : Hubungan antara variabel peranan internet dan motivasi belajar tidak signifikan.

b. H1: Hubungan antara variabel peranan internet dan motivasi belajar signifikan.

Patokan Pengambilan Keputusan

a. Jika Probabilitas atau Signifikasi > 0,05 maka terima H0 : artinya tidak ada pengaruh peranan internet terhadap motivasi belajar mahasiswa.

b. Jika Probabilitas atau signifikasi < 0,05 maka tolak H0 : artinya terdapat pengaruh dari peranan internet terhadap motivasi belajar mahasiswa. 
7) Keputusan : Berdasarkan hasil analisis korelasi product moment pada tabel tersebut di atas, diketahui besarnya nilai koefisien korelasi adalah 0,726 dengan nilai Sig sebesar $0,000<0,05$. Hal ini berarti menunjukkan hubungan yang signifikan antara peranan internet dengan motivasi belajar mahasiswa. Kesimpulan yang dapat diambil adalah hubungan antara peranan internet terhadap motivasi belajar kuat signifikan dan searah dengan kata lain jika mahasiswa selalu menggunakan internet sebagai motivasi belajar maka prestasi belajar akan naik atau meningkat.

\section{Regresi Linear Peranan Internet dengan Motivasi Belajar}

Besarnya pengaruh dari peranan internet terhadap motivasi belajar siswa ditunjukkan dengan nilai koefisien determinasi atau R2 yaitu ditunjukkan dari hasil analisis regresi sebagai berikut 1.3:

Pada tabel tersebut (tabel 1.3), besarnya nilai koefisien determinasi R2 adalah 0,726 angka tersebut memberikan petunjuk bahwa peranan internet berpengaruh terhadap motivasi belajar mahasiswa sebesar 72,60\%. Sisanya sebesar 27,40\% merupakan variasi atau pengaruh variabel lain yang tidak diteliti dalam kajian ini. Misalnya, latarbelakang orang tua, prasarana belajar kampus, dan buku paket belajar dan lain-lain.

Pengujian hipotesis dengan hasil regresi tersebut dilakukan dengan uji t, melalui hasil pengolahan data yang dijelaskan pada tabel coefficient sebagai berikut:

Model Summary ${ }^{b}$

\begin{tabular}{|c|c|c|c|c|}
\hline Model & $\mathrm{R}$ & R Square & $\begin{array}{c}\text { Adjusted } \\
\text { R Square }\end{array}$ & $\begin{array}{c}\text { Std. Error of } \\
\text { The Estimate }\end{array}$ \\
\hline 1 &, $726^{\mathrm{a}}$ &, 527 &, 516 & 1,349 \\
\hline
\end{tabular}

a. Predictors : (Constant), Motivasi dan Prestasi belajar

b. Dependent Variable : Manfaat Internet

Tabel 1.3

Hasil Pengolahan SPSS (Model Summary) 
Coefficients $^{\mathbf{a}}$

\begin{tabular}{|c|c|c|c|c|c|}
\hline \multirow[b]{2}{*}{ Model } & \multicolumn{2}{|c|}{$\begin{array}{c}\text { Unstandardized } \\
\text { coefficients }\end{array}$} & \multirow{2}{*}{$\begin{array}{c}\begin{array}{c}\text { Standardized } \\
\text { Coefficients }\end{array} \\
\text { Beta }\end{array}$} & \multirow[b]{2}{*}{$\mathbf{t}$} & \multirow[b]{2}{*}{ Sig. } \\
\hline & B & $\begin{array}{l}\text { Std.E } \\
\text { rror }\end{array}$ & & & \\
\hline $\begin{array}{l}\text { 1.(constant) } \\
\text { Motivasi dan } \\
\text { prestasi } \\
\text { belajar }\end{array}$ & $\begin{array}{l}\mathbf{5 , 9 3 3} \\
, 727\end{array}$ & $\begin{array}{r}2,053 \\
, 105\end{array}$ & ,726 & $\begin{array}{r}2,889 \\
6,927\end{array}$ & $\begin{array}{l}, 006 \\
, 000\end{array}$ \\
\hline
\end{tabular}

a. Dependent Variable : Manfaat Internet

Tabel 1.4

Hasil Pengolahan SPSS (Coefficients)

Pada tabel coefficient tersebut (tabel 1.4) diperoleh persamaan regresi dan untuk masing-masing parameter individual variable yang regresi, yaitu:

$$
\begin{aligned}
& Y=b o+b x \\
& Y=5,933+0,727 X
\end{aligned}
$$

Dari persamaan tersebut dapat dijelaskan model persamaan regresi sebagai berikut :

a) Besarnya koefisien konstanta (bo) $=5,933$ dengan nilai $\mathrm{t}$ hitung sebesar 2,889 pada nilai Sig 0,000 $<0,05$ yang berarti bahwa koefisien signifikan berpengaruh. Nilai bo sebesar 5,933 dapat diartikan bahwa nilai motivasi sebesar 5,933 satuan apabila peranan internet sama dengan Nol.

b) Besar koefisien regresi variabel peranan internet $(\mathrm{bx})=0,105$ dengan nilai $t$ hitung sebesar 6,927 pada nilai Sig $0,000<0,05$ yang berarti koefisien regresi untuk peranan internet adalah signifikan berpengaruh, Nilai koefisien bx sebesar 0,105 memberikan arti setiap peningkatan 
peranan internet dapat meningkatkan motivasi belajar sebesar 0,105 satuan.

\section{B. Pembahasan}

\section{Pemanfaatan Internet sebagai Media Pengajaran}

Dalam suatu proses belajar mengajar, ada dua unsur yang amat penting adalah metode mengajar dan media pembelajaran. Kedua aspek ini saling berkaitan dan pemilihan metode akan mempengaruhi jenis media pembelajaran yang sesuai meskipun masih ada hal lain yang harus diperhatikan dalam memilih media, antara lain tujuan pembelajaran, dan konteks pembelajaran termasuk karakteristik mahasiswa. Meskipun demikian dapat dikatakan bahwa salah satu fungsi utama media pembelajaran adalah sebagai alat bantu mengajar yang turut mempengaruhi iklim, kondisi dan lingkungan belajar yang ditata dan diciptakan oleh dosen.

Seperti yang dikemukakan oleh Prof Dr. Azhar Arsyad, MA adalah bukunya media pembelajaran yang dikutip dari pendapatnya Hamalik mengemukakan bahwa: "Media pembelajaran dalam proses belajar mengajar dapat membangkitkan keinginan dan minat yang baru, membangkitkan motivasi dan rangsangan kegiatan belajar, dan bahkan membawa pengaruh psikologi terhadap mahasiswa. Penggunaan media pembelajaran pada tahap orientasi pembelajaran akan sangat membantu keefektifan proses pembelajaran dan penyampaian pesan dan ini pelajaran pada saat itu. Selain itu dapat juga membantu mahasiswa meningkatkan pemahaman, menyajikan data dengan menarik dan terpercaya, memudahkan penafsiran data dan memadatkan informais."19

Media pembelajaran meliputi segala sesuatu yang dapat membantu pengajaran dalam menyampaikan materi pembelajaran, sehingga dapat meningkatkan motivasi, daya pikir, dan pemahaman peserta didik terhadap materi yang sedang dibahas menggunakan media pembelajaran. Artinya jika pengajar dalam proses pembelajarannya tidak dan mencapai tujuan yang hendak dicapai dan telah

19 Azhar Arsyad, Media Pembelajaran, Cet. XIII, PT. Raja Grafindo Persada, Jakarta. 2010. Hlm. 15 
dirumuskan sebelumnya. ${ }^{20}$ Dengan berbagai informasi lainnya mulai dari yang paling sederhana, seperti disajikan oleh berbagai surat kabar atau majalah tanpa berlangganan. Demikian juga Kitao mengatakan bahwa :

Melalui internet, peserta didik dpat mengakses berbagai informasi yang menggunakan media pembelajaran sampai pada hal-hal yang berkaitan dengan perkembangan sosial, ekonomi, budaya, politik, ilmu pengetahuan dan teknologi seperti yang dikemukakan oleh Dr. Munir, M.IT yang dikutip dari pendapatnya:

"Seseorang dapat mengakses berbagai referensi, baik yang berupa hasil penelitian maupun artikel kajian dalam berbagai bidang, tidak lagi harus secara fisik pergi ke perpustakaan untuk mencari berbagai referensi sebab internet merupakan perpustakaan yang terbesar dari perpustakaan yang ada dimanapun"21

Informasi yang tersedia dan dapat diakses melalui internet tidak hanya yang ada atau terjadi disuatu negara saja tetapi juga terjadi di seluruh penjuru dunia (global world). Artinya, perkembangan yang terjadi di berbagai negara dapat dengan cepat diketahui oleh banyak orang. Demikian juga dengan informasi yang menyangkut pendidikan/pembelajaran. Apabila peserta didik mempunyai kebebasan memilih, apakah akan memanfaatkan materi pembelajaran elektronik atau tidak. Dalam hal ini tidak ada kewajiban/keharusan bagi peserta didik untuk mengakses pembelajaran elektronik. Sekalipun sifatnya opsional, peserta didik yang memanfaatkannya tentu akan memiliki tambahan pengetahuan atau wawasan. Walaupun materi pembelajaran elektronik berfungsi sebagai tambahan tetapi para guru tentunya akan senantiasa mendorong, menggugah, atau menganjurkan para pembelajarannya untuk mengakses materi pembelajaran elektronik yang telah disediakan.

Internet berfungsi sebagai komlemen (pelengkap), apabila materi pembelajaran elektronik diprogramkan untuk melengkapi materi pembelajaran yang diterima peserta didik di dalam kelas. Sebagai komplemen berarti materi pembelajaran elektronik diprogramkan untuk menjadi materi reinforcement (pengayaan) yang

20 Munir. Dr. MT.IT, "Kurikulum Berbasis Teknologi Informasi dan Komunikasi", Penerbit: ALFABETA Bandung: 2008, hlm. 138

${ }^{21}$ Ibid, hlm. 197 
bersifat enrichment atau remedial bagi peserta didik di dalam mengikuti kegiatan pembelajaran konvensional (tatap muka).

\section{Faktor Pendukung dan Penghambat Pemanfaatan Internet sebagai Media Pembelajaran}

Dalam hal ini yang menjadi faktor pendukung dan penghambat dalam pemanfaatan internet sebagai media pembelajaran adalah Hardware, Software, dan Brainware. Seperti yang dikemukakan oleh Aristo Candra dalam bukunya 30 menit merakit computer, ia mengatakan bahwa :

"Agar computer bisa memberikan hasil yang optimal maka computer harus mempunyai hardware yang berfungsi sebagai masukan (input) adalah perangkat keras yang dapat digunakan untuk menerima/memasukkan data yang akan diolah computer, hardware, yang berfungsi sebagai pemroses adalah perangkat keras yang dapat mengolah data dari masukan dan diterjemahkan menjadi data yang siap untuk disajikan. Dan hardware yang berfungsi sebagai keluaran (output) adalah perangkat keras yang dapat menampilkan data hasil dari proses yang dapat dimengerti dan dipahami secara fisik"22

Dalam mengakses internet, kita memerlukan perangkat keras (hardware) dan perangkat lunak (software) yang memadai. Perangkat keras adalah komponenkomponen fisik yang membentuk suatu sistem computer serta peralatan-peralatan lain yang mendukung computer dalam melakukan tugasnya. Sedangkan perangkat lunak adalah program-program yang diperlukan untuk menjalankan perangkat keras (hardware) komputer.

Seperti yang dikemukakan oleh Hariningsih dalam bukunya Teknologi Informasi yang dikutip dari pendapatnya Prianggono mengemukakan bahwa :

"Perangkat keras yang dibutuhkan untuk internet minimal memenuhi standar, (1) Personal computer $(P C)$ minimal jenis AT-386 dengan memori 2-4 MB, Random Access Memory (RAM) 1 MB, keyboard, mouse, dan monitor color, (2) Jaringan telephone yang berdiri sendiri, (3) Modem dengan kecepatan 14.400$28.000 \mathrm{Kbps}$, (4) Sambungan dengan Internet dapat dioperasikan dengan baik

${ }^{22}$ Arista Candra, 30 Menit Merakit Komputer, Galang Press, Yogyakarta 2008, hlm. 18 
menurut Prianggono minimal memenuhi standart, (1) System operasi dengan graphical user interface (GUI) seperti windows dan linux, (2) Perangkat lunak untuk mengakses dari web yaitu browser misalnya, Microsoft Internet Explorer Netcape Navigator"23

Peranana dosen dalam proses belajar mengajar belum dapat digantikan oleh mesin, radio, tape recorder ataupun oleh komputer sekalipun. Karena masih terlalu banyak unsur-unsur manusiawi seperti sikap, sistem nilai, perasaan, motivasi, kebiasaan dan lain-lain. Yang diharapkan hasil dari proses mengajar tidak dapat dicapai melalui alat-alat tersebut. Seperti yang dikemukakan oleh Dr. Nana Sudjana dalam bukunya dasar-dasar proses belajar mengajar yang dikutip dari pendapatnya Cooper mengatakan bahwa:

"Ada empat kompetensi guru : (1) Mempunyai pengetahuan tentang belajar dan tingkah laku manusia, (2) Mmepunyai pengetahuan dan menguasai bidang studi yang dibinanya, (3) Punya sikap yang tepat tentang diri sendiri, kampus, teman sejawat, dan bidang studi yang dibinanya, (4) Mempunyai keterampilan teknik mengajar." 24

\section{Penyediaan Fasilitas Internet dalam Proses Belajar Mengajar}

Dengan adanya lab Internet, para dosen dan mahasiswa dimudahkan dalam upaya pemanfaatan media internet untuk meningkatkan mutu pendidikan secara umum diharapkan langsung dapat mengubah tatanan kehidupan manusia, demikian halnya dalam sistem pendidikan karena sistem pendidikan nasional senantiasa harus dikembangkan sesuai dengan kebutuhan dan perkembangan yang terjadi baik di tingkat local, nasional, dan global.

Dalam pemanfaatan keberadaan media internet, terdapat kendala-kendala yang dialami dalam oleh kedua belah pihak (Dosen dan Mahasiswa). Beberapa kendala yang dialami dalam memanfaatkan media internet, antara lain:

1) Kurangnya penguasaan bahasa inggris

\footnotetext{
${ }^{23}$ Hariningsih “Teknologi Informasi” Penerbit: Graha Ilmu, Yogyakarta 2005, hlm. 139

24 Dr. Nana Sudjana, Dasar-Dasar Proses Belajar Mengajar, Penerbit: Sinar Baru, Bandung, 1991
} 
Suka atau tidak suka, sebagia informasi di internet tersedia dalam bahasa inggris. Oleh karena itu, penguasaan bahasa inggris menjadi salah satu syarat dalam pemanfaatan internet secara optimal.

2) Akses internet masih mahal

Meskipun sudah tersedia, akses internet masih mahal. Namun hal ini diharapkan agar menjadi lebih murah di masa yang akan datang. Mekanisme lain adalah adanya subsidi dari pemerintah untuk instansi pendidikan.

3) Dosen belum siap untuk menggunakan internet

Dosen masih belum siap untuk menggunakan internet sebagai bagian dari pengajarannya. Padahal dosen merupakan salah satu pengguna yang dapat memanfaatkan internet sebaik-baiknya. Salah satu contohnya adalah mencari soal-soal latihan untuk kelasnya. Jika setiap dosen membuat 3 soal latihan dan disimpan di internet, maka ada ribuan soal yang dapat digunakan untuk latihan di kelas.

Berdasarkan penjelasan tersebut, dapat dibuktikan bahwa internet memiliki pengaruh dalam motivasi belajar mahasiswa. Namun perlu disadari masih adanya sejumlah kendala yang harus dihadapi dalam dunia pendidikan seperti yang telah dijelaskan.

\section{Kesimpulan}

Berdasarkan hasil analisis regresi peranan internet dalam meningkatkan motivasi belajar mahasiswa dapat disimpulkan hal-hal sebagai berikut:

1) Terdapat korelasi antara peranan internet dalam meningkatkan motivasi belajar mahasiswa yang dibuktikan dengan besaran nilai koefisien korelasi sebesar 0,726 dengan sig $0,000<0,05$ berarti berkorelasi secara signifikan.

2) Hasil regresi diperoleh koefisien determinasi Adjusted R2 sebesar 0,726 angka tersebut memberikan petunjuk bahwa peranan internet berpengaruh terhadap motivasi belajar mahasiswa sebesar 72,60\% sisanya sebesar $27,40 \%$ merupakan variasi atau pengaruh variabel lain yang tidak diteliti 
dalam kajian ini. Misalnya, latar belakang orang tua, prasarana belajar kampus, dan buku paket belajar dan lain-lain.

3) Hasil regresi antara peranan internet terhadap motivasi belajar mahasiswa diperoleh persamaan sebagai berikut :

a) Besarnya koefisien konstanta (bo) $=5,933$ dengan nilai $\mathrm{t}$ hitung sebesar 2,889 pada nilai Sig 0,000 < 0,05 yang berarti bahwa koefisien signifikan berpengaruh. Nilai bo sebesar 5,933 dapat diartikan bahwa nilai motivasi sebesar 5,933 satuan apabila peranan internet sama dengan Nol.

b) Besar koefisien regresi variabel peranan internet $(\mathrm{bx})=0,105$ dengan nilai t hitung sebesar 6,927 pada nilai Sig $0,000<0,05$ yang berarti koefisien regresi untuk peranan internet adalah signifikan berpengaruh, Nilai koefisien bx sebesar 0,105 memberikan arti setiap peningkatan peranan internet dapat meningkatkan motivasi belajar sebesar 0,105 satuan.

\section{Saran}

Bertitik tolak dari uraian penjelasan dan hasil analisis yang telah dijelaskan tersebut, maka beberapa hal yang dapat direkomendasikan sebagai saran antara lain :

1) Peranan positif internet perlu ditingkatkan dengan tidak mengabaikan adanya dampak negatifnya.

2) Untuk memaksimalkan peranan internet para mahasiswa dan dosen perlu memiliki pedoman kerja atau program yang jelas dalam proses belajar mengajar.

3) Peranan kampus dalam penyediaan sarana dan prasarana dalam menunjang proses belajar mengajar perlu diitngkatkan dan difasilitasi dengan baik.

4) Hasil peneliitan ini dapat dijadikan rujukan dan perlu dilakukan penelitian lanjut, hasilnya dengan perguruan tinggi yang lebih lengkap dalam hal teknologi. Sehingga akan mendapatkan hasil yang komprehensif tentang 
peranan dalam pendidikan, khususnya untuk meningkatkan motivasi belajar mahasiswa. 


\section{Daftar Pustaka}

Wahidmumin, Cara Mudah Menulis Proposal dan Laporan Penelitian Lapangan (Malang: UM Press, 2008).

Anonim (2008) Kamus Istilah Internet. (www.wikipedia.com) diakses 24 April 2012.

Anonim. (2008). Sekilas Perkembangan Internet di Indonesia. www.jurnalkopertis4.org. diambil 24 April 2012.

Arif A Mangkoesapoetro. (2004). Pemanfaatan Media Massa Sebagai Sumber Pembelajaran Di Tingkat Persekolahan. (http://artikel.us/mangkoes6-042.html) diakses 27 Februari 2006.

Andhika. (2005). Apa itu Internet ? (www.andhika.com) diakses 25 Februari 2006.

Marsell Ruben Payong (2005). Good Bye Teacher. (www.kompas.com) diakses 24 Februari 2006.

Philip Rechdalle. (2005). Internet dan Pendidikan (www.pendidikan.net) diakses 24 Februari 2006.

Munir, DR. MIT , "Kurikulum Berbasis Teknologi Informasi dan komunikasi", Penerbit: ALFABET, Bandung 2008.

Hariningsih, “Teknologi Informasi”, Penerbit : Graha Ilmu, Yogyakarta 2005.

Sutejo Budi, "e-Education, Konsep Teknologi dan Aplikasi Internet Pendidikan”, Penerbit : Andi Yogyakarta 2002.

Marsell Ruben Payong (2008). Good Bye Teacher. (www.kompas.com) diakses 24 Mei 2012. 
Philip Rechdalle (2008). Internet dan Pendidikan. (www.pendidikan.net) diakses 24 Mei 2012.

http://www.artikel.us/mangkoes6-04-2.html diakses 25 Juni 2012.

Azwar, Metode Penelitian, (Yogyakarta Pusat Belajar, 2005).

Iqbal, Analisis Data Penelitian dengan Statistik : PT. Bumi Aksara, 2008.

Margono. S. Metodologi Penelitian Pendidikan, (Jakarta: Rineka Cipta, 2007).

Sugiyono, Metode Penelitian Administrasi (Bandung: Penerbit Alfabeta, 1999).

Azhar Arsyad, Media Pembelajaran, Cet. XIII, PT. Raja Grafindo Persada, Jakarta 2010.

Arista Candra, 30 Menit Merakit Komputer, Galang Press, Yogyakarta 2008.

Dr. Nana Sudjana, Dasar-Dasar Proses Belajar Mengajar, Penerbit Sinar Baru, Bnadung. 1991.

Cornelius Trihendradi, Step By Step SPSS 13 Analisis Data Statistik, Penerbit ANDI Yogyakarta, 2005

Wahid Sulaeman, Jalan Pintas Menguasai SPSS 10, Penerbit ANDI Yogyakarta, 2002. 